AL-Qadisiya Journal of Vet.Med.Sci. of $5^{\text {th }}$ conference 21-22 Nov. 2012

Vol. 11

No. 3

2012

\title{
Immunosuppressive Properties of Infectious Bronchitis Vaccine4/91 strain against different programs and method of vaccination against Newcastle disease in Broilers
}

\author{
A.H. Zahid I. K. Latif T.K-AL-Alwany \\ Faculty of Veterinary Medicine,University of Baghdad,Iraq
}

\begin{abstract}
Infectious bronchitis virus (IBV) primarily induces a respiratory disease in broilers causing important economic losses in poultry industry. The aim of this study was to investigate the immunosuppressive properties of live IB vaccine on the different programs and method of vaccination against Newcastle disease (ND) in broilers. A total of 125 one-day-old broiler chicks were assigned into five equal groups. At day one G1 and G2groupswere vaccinated with a live (ND, IB)vaccine by dipping the head in the vaccine and intra-cloacae method respectively. Afterward, G3and G4 groups were vaccinated with a live ND vaccine alone by the same method of $\mathrm{G} 1$ and $\mathrm{G} 2$. At the same time all these4 groups were vaccinated by subcutaneous injection (S/C) with inactivated oil based vaccine ND. The G5 group was left without vaccination as a control group. After that, all treated groups were vaccinated with a live ND by spray method at day 10 of the age. The immunosuppressive effects of this IB virus was evaluated by Haemagglutination inhibition test (HI), and challenged by virulent ND virus. Bursa and Spleen indices were estimated in all groups. The results showed that the antibody titers against ND was higher $(\mathrm{P}<0.05)$ in G3and G4 in compared with G1, G2 and control groups at 20 and 30 days of age. However, there was no significant difference of bursa index and spleen index in all groups. Challenge test showed no mortality in the $3^{\text {rd }}$ group while $10 \%$ in the $4^{\text {th }}$ group, $85 \%$ in the $1^{\text {st }}$ group and $90 \%$ in the $2^{\text {nd }}$ group. In conclusion it's revealed that the best method and program of vaccination which can protect against ND was applied in the $3^{\text {rd }}$ group.
\end{abstract}

\section{Introduction}

Poultry industry has expanded rapidly over the last fourth decades and is playing a vital role in the economy of the country. However, the industry is confronted with a variety of problems, particularly the diseases of viral origin.(2).Infectious bronchitis virus is the prototype species of the family Coronaviridae, more than 25 genotypes are distributed worldwide. IBV causes an acute highly contagious viral respiratory disease of chickens which is characterized by respiratory rales, coughing and sneezing .(7). Some of IBV strains replicate in the gastrointestinal tract, oviduct, kidney, and due to their nephropathogenic properties they have the potential to cause severe losses with up to $44 \%$ mortality. $(7 ; 8)$. In other cases, infection of the proventriculus leads to $75 \%$ to $100 \%$ mortality in young
birds.(9).Newcastle disease is regarded throughout the world as one of the important diseases of poultry and other birds.(1).The mortality rates up to $100 \%$,especially in unvaccinated flocks.(4).Because of the severe nature of the disease and the associated consequences, ND is included as an Office International des Epizooties, (OIE) list a disease and most countries, including all European Union countries, enforce statutory control measures in the event of outbreaks of disease. (5).Control of these diseases depends on biosecurity procedures and vaccination . Attenuated live and inactivated oil-emulsion vaccines are generally effective in controlling the disease. However, IB outbreaks may occur despite the use of the vaccine. Earlier studies have reported that IB virus interferes with the 
AL-Qadisiya Journal of Vet.Med.Sci. of $5^{\text {th }}$ conference 21-22 Nov. 2012

Vol. $11 \quad$ No. 3

immune response against ND virus .(15;14).

This study was conducted to evaluate the different methods and program to found the best solution of problem to ND infection,

\section{Materials and Methods}

\section{Vaccines}

Vaccines of ND commercial vaccine CL30, inactivated oil based vaccine of ND lasota strain, IB vaccine 491 strains, all vaccines supplied from Intervet Company.

\section{Method of vaccination}

Dipping method was applied by dipping head of birds in the vaccine solution of ND alone(1000dose per litter) for short period, or mixed vaccines IB and ND; both vaccines dissolved in one litter of distil water. Those vaccines were given at one-day-old with inactivate oil bused ND vaccine injected subcutaneously in the back region of the neck at a dose of $0.25 \mathrm{ml}$ according to the recommendation of Intervet Company.

Intra-cloacae method was applied by given the dissolved vaccines of ND alone $(1000$ dose per litter) or mixed ND and IB, both vaccines dissolved in one litter of distil water and by injection one $\mathrm{ml}$ of diluted vaccine in intra-cloacae at day-old with inactivate oil bused ND vaccine injected subcutaneously in the back region of the neck at a dose of $0.25 \mathrm{ml}$.

Spraying method was applied as a booster dose was given by spraying of Lasota vaccine at day10of age to all vaccinated groups.

\section{Experimental animals and protocol}

One hundred and twenty five one-day-old broiler(Cobb strain) chicks obtained from a local hatchery were kept at the Department of pathology and poultry disease, college veterinary medicine, University of Baghdad. Upon arrival, the chicks were divided randomly into five equal groups of 25 chicks each. First group G1 was vaccinated at oneday-old with IB and ND vaccine using dipping method and inactivated oil based vaccine $\mathrm{S} / \mathrm{C}$ at one-day-old. Second group G2 was vaccinated at one-day-old with IB and also to detect the immunosuppression caused by IB vaccine on immune response of ND vaccine.

and ND vaccine using intra-cloacae method and inactivated oil based vaccine $\mathrm{S} / \mathrm{C}$ at oneday-old. Third group G3 was vaccinated atone-day-old by ND vaccine only by dipping of head and inactivated oil based vaccine $\mathrm{S} / \mathrm{C}$ at one-day-old. Forth group G4 was vaccinated at day one old by ND vaccine using intra-cloacae method of vaccine and inactivated oil based vaccine S/C at one-day-old. Fifth group G5 was lifting un vaccinated as control group. Spraying method was applied as a booster dose was given by spraying of Lasota vaccine at day 10 of age to all vaccinated groups.

Blood samples were randomly collected from ten birds from each group at 20 and 30 days for $\mathrm{HI}$ test to determine the antibody titer of NDV. (3). Chickens were individually weighed from each group to determine their body weight. Five birds from each group at day 20 were sacrificed via cervical dislocation. Following a thorough visual appraisal, the bursa Fabricious and spleen were immediately removed, dry and individually weighed. Since substantial lymphoid organ weight change was anticipated, their indices were calculated .(10). Using these formula: Organ index = organ weight $(\mathrm{g}) / \mathrm{BW}$ (g) x 100.Challenge test is applied 30 days and observation for 7 day after challenge to record clinical signs, gross lesion and mortality. The chickens were raised according to routine practice in terms of light and temperature. Water and feed were given ad libitum. The data were analyzed with SPSS 16.0 for Windows by using one-way analysis of variance and least significance differences to determine the difference between groups at level of $\mathrm{P}<0.05$. 
AL-Qadisiya Journal of Vet.Med.Sci. of $5^{\text {th }}$ conference 21-22 Nov. 2012

Vol. 11

No. 3

2012

\section{RESULTS}

The values of HI titer in vaccinated groups against ND at 20 and 30 days of age showed significance of increase of $\mathrm{Ab}$ titers in compared with control group as illustrated in table (1).A trend of an increase of antibody

titer was seen in all groups except that in control group during the course of experiment. At these instants, Ab titer in the G3 and G4 was significantly $(\mathrm{P}<0.05)$ different from the G1 and G2.

Table (1) the value of Abs titer of HI against NDV at 20,30 days of age all experimental groups.

\begin{tabular}{|l|c|c|l|}
\hline Groups & $\begin{array}{c}\text { Mean } \pm \text { SE at } 20 \\
\text { day of age }\end{array}$ & $\begin{array}{c}\text { Mean } \pm \text { SE at 30 day } \\
\text { of age }\end{array}$ & \multicolumn{1}{|c|}{$\begin{array}{c}\text { Vaccines \&Method of } \\
\text { vaccination }\end{array}$} \\
\hline G1 & $8.0 \pm 2.80^{\mathrm{b}}$ & $10 \pm 1.7^{\mathrm{b}}$ & $\begin{array}{l}\text { Alive ND and IB, } \\
\text { dipping\& oily ND }\end{array}$ \\
\hline G2 & $6.0 \pm 1.40^{\mathrm{b}}$ & $9.0 \pm 2.5^{\mathrm{b}}$ & $\begin{array}{l}\text { Alive ND and IB, intra- } \\
\text { cloacae \&oily ND }\end{array}$ \\
\hline G3 & $18 \pm 5.25^{\mathrm{a}}$ & $40 \pm 8.0^{\mathrm{a}}$ & $\begin{array}{l}\text { Alive ND only, dipping } \\
\text { \&oily ND }\end{array}$ \\
\hline G5 & $16 \pm 8.45^{\mathrm{a}}$ & $36 \pm 10^{\mathrm{a}}$ & $\begin{array}{l}\text { Alive ND only, intra- } \\
\text { cloacae \&oily ND }\end{array}$ \\
\hline
\end{tabular}

a, b, ${ }^{c}$ Values bearing similar superscript between column do not differ at $(\mathrm{P}<0.05)$.

The bursa and spleen indices are shown in table (2), the result showed significant control group, highest mean values were differences between treated groups and recorded in treated groups while a less mean value in control group at day $20^{\text {th }}$ of age.

Table (2) the results of bursa and spleen indices all experimental groups

\begin{tabular}{|c|c|c|}
\hline Group & Bursa (Mean \pm SE) & Spleen (Mean \pm SE) \\
\hline G1 & $0.150 \pm 0.012^{\mathrm{a}}$ & $0.125 \pm 0.030^{\mathrm{a}}$ \\
\hline G2 & $0.130 \pm 0.009^{\mathrm{a}}$ & $0.100 \pm 0.026^{\mathrm{a}}$ \\
\hline G3 & $0.140 \pm 0.160^{\mathrm{a}}$ & $0.130 \pm 0.015^{\mathrm{a}}$ \\
\hline G4 & $0.150 \pm 0.023^{\mathrm{a}}$ & $0.125 \pm 0.026^{\mathrm{a}}$ \\
\hline G5 & $0.110 \pm 0.019^{\mathrm{a}}$ & $0.080 \pm 0.029^{\mathrm{a}}$ \\
\hline
\end{tabular}

Values bearing similar superscript between column do not differ at $(\mathrm{P}<0.05)$. 
AL-Qadisiya Journal of Vet.Med.Sci. of $5^{\text {th }}$ conference 21-22 Nov. 2012

Vol. 11

After challenge test, the first clinical sign of chicks was observed in the unvaccinated control group which characterized by the
No. 3

respiratory sign, diarrhea, nervous signs and high mortality percentage was reached $100 \%$ table (3).

Table (3) Mortality rate after challenge test in all experimental groups

\begin{tabular}{|c|c|c|l|c|}
\hline Group & Dead No. & $\begin{array}{c}\text { Total } \\
\text { No. }\end{array}$ & \multicolumn{1}{|c|}{$\begin{array}{c}\text { Vaccines \&Method of } \\
\text { vaccination }\end{array}$} & Mortality rate \\
\hline G1 & 17 & 20 & $\begin{array}{l}\text { Alive ND and IB, dipping \& } \\
\text { oily ND }\end{array}$ & $85 \%$ \\
\hline G2 & 18 & 20 & $\begin{array}{l}\text { Alive ND and IB, intra- } \\
\text { cloacae \& oily ND }\end{array}$ & $90 \%$ \\
\hline G3 & 0 & 20 & $\begin{array}{l}\text { Alive ND only, dipping \& } \\
\text { oily ND }\end{array}$ & $0 \%$ \\
\hline G4 & 2 & 20 & $\begin{array}{l}\text { Alive ND only, intra-cloacae } \\
\text { \& oily ND }\end{array}$ & $10 \%$ \\
\hline G5 & 20 & 20 & \multicolumn{1}{|c|}{ Control } & $100 \%$ \\
\hline
\end{tabular}

Nevertheless, high protective rate was recorded in G 3 and G4 were reached $100 \%$, $90 \%$ respectively as illustrated in table (4).

Table (4) Protection rate after challenge test in all experimental groups

\begin{tabular}{|c|c|c|c|c|}
\hline Group & Dead No. & $\begin{array}{c}\text { Total } \\
\text { No. }\end{array}$ & \multicolumn{1}{|c|}{$\begin{array}{c}\text { Vaccines \&Method of } \\
\text { vaccination }\end{array}$} & Protection rate \\
\hline G1 & 17 & 20 & $\begin{array}{l}\text { Alive ND and IB, dipping } \\
\text { \&oily ND }\end{array}$ & 15 \\
\hline G2 & 18 & 20 & $\begin{array}{l}\text { Alive ND and IB,intra- } \\
\text { cloacae \& oily ND }\end{array}$ & $10 \%$ \\
\hline G3 & 0 & 20 & $\begin{array}{l}\text { Alive ND only, dipping \& } \\
\text { oily ND }\end{array}$ & $100 \%$ \\
\hline G4 & 2 & 20 & $\begin{array}{l}\text { Alive ND only, intra-cloacae } \\
\text { \& oily ND Control }\end{array}$ & $90 \%$ \\
\hline G5 & 20 & 20 & \multicolumn{1}{|c|}{ Col } \\
\hline
\end{tabular}

\section{Discussion}

The impact of IB vaccine on immune response on different methods of vaccination against ND was studied to show the important role of interference on humoral response against ND in layers. Our previous work was documented that IB impair the humoral immune response on ND vaccination titer in broilers .(6). The data of $\mathrm{HI} \mathrm{Ab}$ titers revealed that there is a signification difference between the vaccinated groups and control, and also showed that a significance difference in the immune response between G1,G2groups (vaccinated with $\mathrm{ND}+\mathrm{IB}$ )and $\mathrm{G} 3, \mathrm{G} 4$ groups (vaccinated with $\mathrm{ND}$ only) as illustrated in table (2).These data raveled that the higher $\mathrm{HI} \mathrm{Ab}$ titer was due to avoiding gave live IB vaccine with ND vaccine in the same time to prevent the interferes of IB with ND vaccine.(12).determined that mixed IB,ND 
AL-Qadisiya Journal of Vet.Med.Sci. of $5^{\text {th }}$ conference 21-22 Nov. 2012

Vol. 11

vaccine lead to immune suppression and high mortality due to infection with ND. Bursa and spleen indices are useful indicators of immune response, the result showed that high values in vaccinated groups than that of control unvaccinated group. (11). The result of challenge test with virulent local isolated ND strain was evaluated in different vaccinated groups as shown in table(3). High mortality and sever clinical signs were appeared in unvaccinated control group, signs characterized by respiratory signs, diarrhea and nervous signs. Nevertheless, high protective rate in G3 and G4 against ND after challenge by virulent virus respectably $100 \%$, 90\% while G1, G2 had significantly low protection percentage $15 \%, 10 \%$. The immune response of these different methods (dipping \&intra-cloacae)
No. 3

and programs (ND with IB and ND alone) create different stimulation in cell immunity and humoral immunity (local and systemic) leading to stimulation of high Abs titers as showed in groups G3 and G4 or low Ab titer as showed in groups G1 and G2. (12).According to the IB viral replication in the cecal tonsil and bursa Fabricius were affected as a result of the viremia due to live strain of IB vaccine which caused a pathological changes in these organs leads to destruction of lymphatic cell. (13).Also, the hardarian gland which is the target organ of viral replication was affected leading to necrosis of plasma cells, this change mean factors of immunosuppression of immune response as indicated by low Ab titer in G1 an $\mathrm{G} 2$ groups.(14).

\section{References}

1. Alexender, D. J. (2000). Newcastle disease and other avian paramyxoviruses. Office International des Epizooties, Scientific and technical Review19:443- 462.

2. Alexender, D. J. (2008). Newcastle disease virus and other paramyxovirusesinfection. In: Disease of poultry. Eds. By Saif, Y.M. Associated with Barnes, H.J. Fadly, A.M. Glaisson, J.R. McDongald, L.R. and Swayne, D.E., Jr. $11^{\text {th }}$.Ed., Iowa state university press, Ames, Iowa, U.S.A. Pp:63-87.

3. Hanson, R.P. (1980). Newcastle disease .Int: Isolation and identification of Avian pathogen. Eds. By Hitchner, S.B., Domermuth H.C.; Purchase, H.G.and Williams. E.2nd.Ed.The Arnold Printing Co., Itheca, New York. Pp.63-66.

4. Hopper, P.T.,E. Hansson,J.G. Young, G.M. Russell, and A.J.Dellaporta.(1999) lesions in theupper respiratory tract in chickensexperimentally infected with Newcastle disease virus isolated in Australia. Aust. Vet.J 77(1):50-51.

5. Office international des Epizooties (2000).Newcastle disease. Manual of standars for diagnostic tests and vaccines. $4^{\text {th }}$ Edition, OIE, paris, 221232.

6. Zahid, A. H.; Latif.I.K.;AL-Safy.A.K . (2011) Interferring of Infectious Bronchitis Vaccine on the Immune Response of NecastleandAviane Influenza Vaccines in Layers $8^{\text {th }}$ Sci. Con. for Agric. Res. 16 (2): 225-230.

7. Cavanagh D, Naqi S. Infectious bronchitis. In Diseases of Poultry 11th edition. Edited by: Saif YM, Barnes HJ, Glisson JR, Fadly AM, McDougald LR, Swayne DE. Ames: Iowa State University Press; 2003:101-119.

8. Cavanagh D. Coronaviruses in poultry and other birds. Avian Pathol2005, 34:439-448.

9. Yu L, Jiang Y, Low S, Wang Z, Nam SJ, Liu W, Kwang J: Characterization of three infectious bronchitis virus 
AL-Qadisiya Journal of Vet.Med.Sci. of $5^{\text {th }}$ conference 21-22 Nov. 2012

$$
\text { Vol. } 11
$$

isolates from China associated with proventriculus in vaccinated chickens. Avian Dis.2001, 45:416424.

10. Sellers, R.S., D. Morton, B. Michael, N. Roome, J. Johnson and K. Schafer. 2007. Society of toxicologic pathology position paper: Organ weight recommendations for toxicology studies. Toxicol. Pathol.35: 751-755.

11. Kapczynski, D.R., H.S. Sellers, G.N. Rowland and M.W. Jackwood. 2002. Detection of in ovoinoculated infectious bronchitis virus by immunohistochemistry and in situ hybridization with a riboprobe in epithelial cells of the lung and cloacal bursa. Avian Dis. 46: 679-685.

12. Nakamura, K., Narita,M and Imai, K. 1992. The effect of mixed live vaccines of $\mathrm{ND}$ and IB on the chicken respiratory tract. J. Com.

Pathol. 106: 341-350.
No. 3

13. Gelb, J. 2003. Replication interference associated with infectious bronchitis and Newcastle disease virus co-infection. World Veterinary Poultry Association Convention Notes 35: 625-689.

14. Cardoso, W.M., AguiarFilho, J.L.C., Romão, J.M., Oliveira, W.F., Salles, R.P.R., Teixeira, R.S.C. Sobral, M.H.R. 2005. Effect of associated vaccines on the interference between Newcastle disease virus and infectious bronchitis virus in broilers.Brazilian Journal of Poultry Science 7: 181184.

15. Yachida, S., E. Kuwahara, Y. Irirtani and Y. Hayashi. 1986. Egg interference of embryo non-lethal avian infectious bronchitis viruses (IBV) with velogenic Newcastle disease virus and embryo adapted IBV. Res. Vet. Sci. 40: 1-3.

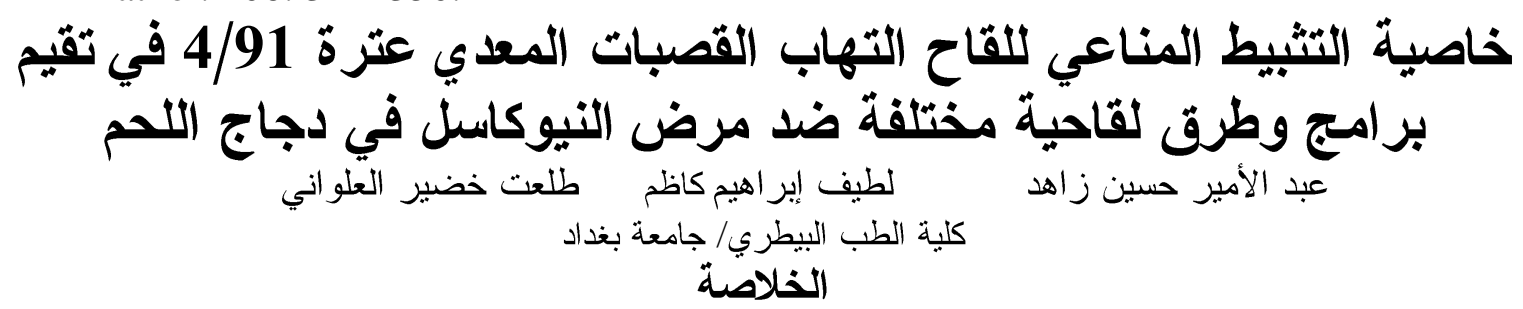

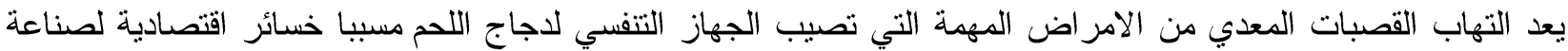

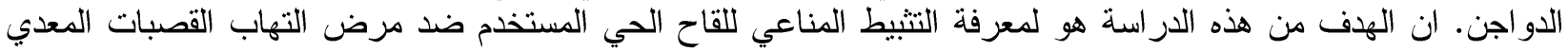

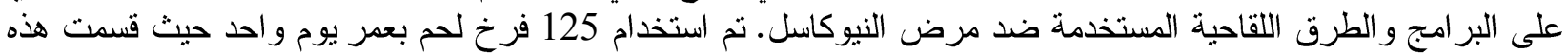

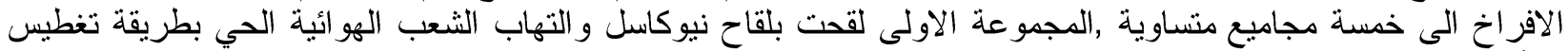
الر أس و اللقاح المبطل الزيتي(نيوكاسل) بطريقة الحقن تحت الجلد بعمر يوم واحد. المجموعة التئة الثانية لقحت بلقاح نيوكاسل و

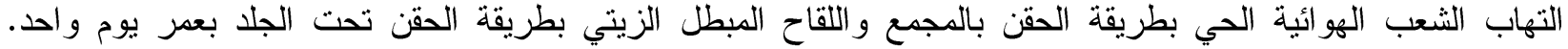

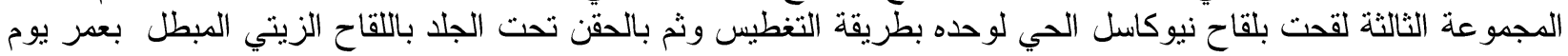

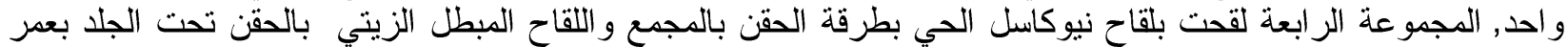

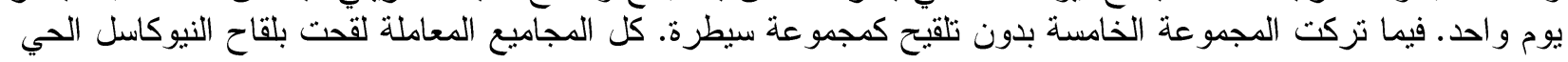

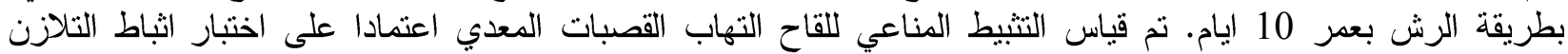

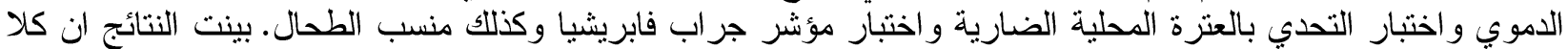

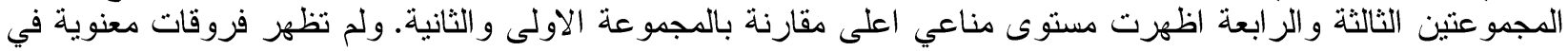
منسب جر اب فابريشيا ومنسب الطحال .اما نتائج اختبار التحدي بالعترة الضارية لفايرة الفايروس نيوكاسل فكانت نسبة الهاكات

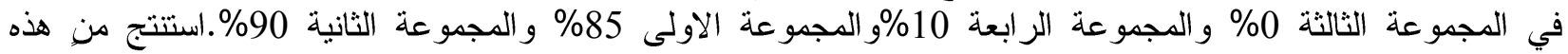

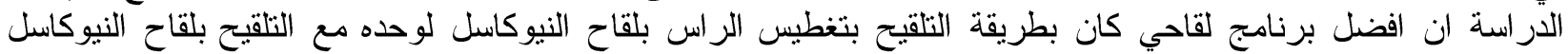
المبطل الزيتي بعمر يوم واحد و الذّي كان في المجموعة الثالثة. 